\title{
THE ROLE AND PLACE OF SPEECHES IN THE WORK OF THEOPHYLACT SIMOCATTA**
}

Speech $(\mu \hat{v} \theta o \varsigma$, oratio), as an element of ancient historical narrative, has been known in classical literature since the breakthrough Histories by Herodotus of Halicarnassus ${ }^{1}$, it demonstrated its full functional capacity in the fundamental History of the Peloponnesian War by Thucydides ${ }^{2}$. The History of the Peloponnesian War set the standards for the historic narrative for the centuries to come ${ }^{3}$, and ancient authors followed these guidelines when creating literary topoi which are continued to be recorded even in contemporary Polish literature ${ }^{4}$. The significance of topology is so dominant in the literary rhetoric tradition that the modern commentators often attribute slavish imitation

* Dr hab. Anna Kotłowska - Assistant professor in Department of Byzantine Studies at the Institute of the History at the Faculty of History of Adam Mickiewicz University in Poznań, e-mail: anna_kotlowska@wp.pl; dr Łukasz Różycki - Assistant professor in Department of Byzantine Studies at the Institute of the History at the Faculty of History of Adam Mickiewicz University in Poznań, e-mail: lukasz.rozycki@amu.edu.pl.

** This paper is part of research project (0028/NPRH2/H11/81/2012) financed by the Polish Ministry of Science and Higher Education.

${ }^{1}$ Cf. B. Mulligan, óp $\alpha$ Introducing Direct Speech in Herodotus, "Mnemosyne" 60 (2007) 281284; L. Solmsen, Speeches in Herodotus' Account of the Battle of Plataea, CPh 39 (1944) fasc. 4, 241-253; O. Murray, Herodotus and Oral History, in: The Historian's Craft in the Age of Herodotus, ed. N. Luraghi, Oxford 2007, 16-44; Ch. Pelling, Speech and Narrative in the Histories, in: The Cambridge Companion to Herodotus, ed. C. Dewald - J. Marincola, Cambridge 2006, 103-121. Good comparative introduction: R.F. Miller, In Words and Deeds. Battle Speeches in History, Hanover - London 2008.

${ }^{2}$ Cf. H.F. Harding, The Speeches of Thucydides. With a General Introduction and Introductions for the Main Speeches and the Military Harangues, Lawrence 1973. See Thucydides as the creator of the topos of fictional orations delivered before a battle: M. Clark, Did Thucydides Invent the Battle Exhortation? "Historia" 44 (1995) 375-376; G. Crane, Thucydides and the ancient simplicity. The limits of political realism, Berkeley 1998.

${ }^{3}$ Cf. J.J. Price, Thucydides and internal war, Cambridge 2001; R.B. Strassler, The Landmark Thucydides: A Comprehensive Guide to the Peloponnesian War, New York 1996; J. de Romilly, Histoire et raison chez Thucydide, Paris 1956.

${ }^{4}$ Cf. T. Sinko, Echa klasyczne w literaturze polskiej, Kraków 1923; S. Stabryła, Antyk we współczesnej literaturze polskiej, Wrocław 1980; I. Lewandowski, Recepcja rzymskich kompendiów historycznych w dawnej Polsce (do połowy XVIII wieku), Poznań 1976. 
to the authors. The later the work was created, the more it could be weighed with topoi not understood by the author and copied from great masters. Such reasoning is flawed and becoming increasingly rare in the contemporary Byzantine studies. The idea behind the "mimesis" was the ability to express new content using classical semantics, resulting from the internal conviction of the superiority of the ancient authors and, concurrently, from the need to continue the identity ${ }^{5}$. What the Byzantines were fascinated with was "amphoteroglossia" gaining new sense by changing the context of the phrase taken from a different text $t^{6}$. The skill to use it was regarded as a proof of the highest literary artistry and the reading became then a game between the author and the reader who, by confronting contemporary reality with classical references, was reading not so much facts as the personal opinion of the author, with a particular focus on assessment.

Nevertheless, one of the victims of earlier prejudices was Theophylact Simocatta (approx. 575-630 AD) ${ }^{7}$, the author of Historiae ${ }^{8}$, a comprehensive synthesis of the last three decades of the $4^{\text {th }}$ century created in the first half of the $7^{\text {th }}$ century. Many historians and philologists considered Theophylact to be a mediocre author, who ineptly and usually thoughtlessly imitated ancient topoi ${ }^{9}$. These opinions, however, were not rooted in an in-depth analysis of the text that could help see Simocatta as an author formed by the standards of

${ }^{5} \mathrm{Cf}$. H. Hunger, On the Imitation (MIMH $\Sigma \mathrm{I} \Sigma$ ) of Antiquity in Byzantine Literature, DOP 23-24 (1969-1970) 15-38; R. Jenkins, The Hellenistic Origins of Byzantine Literature, DOP 17 (1963) $37-52$.

${ }^{6}$ Cf. P. Roilos, Amphoteroglossia. A Poetics of the Twelfth-Century Medieval Greek Novel, Cambridge 2005.

${ }^{7}$ The only specific indication is the allusion to the death of Shahanshah Khosrow in 628 AD, see Theophylactus Simocatta, Historiae V 15, 5-7. The dialogue included in the introduction should be interpreted with this in mind, it was created earlier (confirmed by the emotions used in the presentation of Phokas) but was included in Historiae at the end of the writing process. On the contrary, Nina Pigulevskaya, in the introduction to her translation, believes that the dialogue was written after Historiae had been completed. Феофилакт Симокатта, История, transl. Н.В. Пигулевская - С.П. Кондратьев, Москва 1957, 13.

${ }^{8}$ Cf. Theophylacti Simocattae Historiae, ed. C. de Boor - P. Wirth, Stutgardiae 1972. Hereinafter cited as: Theophylactus Simocatta, Historiae. The English translation was published as The History of Theophylact Simocatta an English Translation with Introduction and Notes, transl. Michael and Mary Whitby, Oxford 1986. Due to differences in Greek and English translation the English translation of the Greek text was made by the authors.

${ }^{9} \mathrm{Cf}$. "Teophylact did not demonstrate a historical sense", in: O. Jurewicz, Historia literatury bizantyńskiej, Wrocław 1984, 107. Karl Krumbacher (Geschichte der byzantinischen Literatur, München 1897, 56-58) expressed his regret that such an interesting end of the $6^{\text {th }}$ century was depicted by so poor a historian... Similarly in: Oxford Dictionary of Byzantium, 1900-1901, where Barry Baldwin describes Theophylact's work as "bombastic", "chronologically unsound" and appreciates it solely for the included documents and relatively poor sources for the turn of the $6^{\text {th }}$ and $7^{\text {th }}$ centuries. The most reliable assessment of Theophylact's prose in textbook-type studies is presented in H. Hunger, Die hochsprachliche profane Literatur der Byzantiner, Bd. 1, München 1978, 313-319. 
the classical paideia, an official of central administration where Latin was still used $^{10}$. Only in the last few decades did Historiae become to be appreciated by historians, taking into consideration the fact that this work is interesting not only because of the unique historical information, but also due to the composition of the text and fragments of official documents included (e.g. correspondence with dignitaries of Sasanian Persia). In this research, the role of Polish academics is growing ${ }^{11}$. There is still, however, a shortage of works that would fully take into account the significance of formal measures in Theophylact's presentation of factual material.

The text below is an attempt, however partial, to fill in that void by analysing the speeches included in the work. The focus will be put on the place of speeches in the work and their purpose rather than on mere content. Our hypothesis is that when composing Historiae, Theophylact consciously used speeches as an important manner of communication with the reader. In our opinion speeches are something more than mere literary topos of aesthetic significance; they also play a vital role in the text's composition, introduce the reader into new issues or convey opinions and deliberations of the author regarding covered events. Proving such a hypothesis is possible only by an indepth historical and philological analysis.

By way of introduction, it should be defined what authors understand as a speech. These are any and all fragments of texts in oratio recta, excluding the quoted letters. Therefore, a speech is both a long monologue of a commander made before an army and one sentence spoken by Maurice at the moment of his death. At this point it should be stressed that the differentiation

${ }^{10}$ Cf. B. Baldwin, Theophylact's Knowledge of Latin, "Byzantion" 47 (1977) 357-360, Bary Baldwin argues that the author was perfectly aware of the Latin origin of the term, however what he had in mind was the contemporary meaning of $\hat{\rho} \hat{\eta} \xi$ used to denote both Frankish kings and lesser European rulers (e.g. Lombards) Theophylactus Simocatta (Historiae VI 10, 13) as opposed to Byzantine $\beta \alpha \sigma \imath \lambda \varepsilon v$ s. Michael Whitby spoke against such thesis, opposing to attributing to Theophylact the knowledge of languages and treated the phrases proving this as mindless imitation of the source. His knowledge of Latin, in Whitby's opinion, was at best limited to administrative terminology. Second argument: inadequacy of using the notion of $\hat{\rho} \hat{\eta} \xi$ to denote a Slavic tribe leader at that time is not reliable and in a comprehensive approach Whitby's reply did not succeed in undermining Baldwin's hypothesis. Cf. M. Whitby, Theophylact's Knowledge of Languages, "Byzantion" 52 (1982) 425-428. Regardless of said discussion: T. Olajos, Données et hypothèses concernant la carrière de Théopbylacte Simocatta, Acta Classica Universitatis Scientiarum Debreceniensis 17-18, Debrecini 1983, 40-41, having collected all fragments of Latin quotations, concluded rightly that the language was a foreign one for him, although to some extent familiar.

${ }^{11}$ Cf. M. Wołoszyn, Teofilakt Simokatta i Stowianie znad Oceanu Zachodniego - najstarsze świadectwo obecności Stowian nad Battykiem, Kraków 2014 (parallel text in German); J. Prostko-Prostyński, "Ziemia ich nie zna żelaza". Glosa do Historiae VI. 2 Teofylakta Simokatty, in: Viator per devia scientiae itinera, red. A. Michałowski - M. Teska - M. Żółkiewski, Poznań 2015, 321326. A riveting discussion between Marcin Wołoszyn and Jan Prostko-Prostyński regarding one only episode from Historiae. This shows how great information potential dwells therein. At this point the erudite nature of both these dissertations should be stressed. 
between oratio recta/oratio obliqua plays an important role in the text's composition both in the formal and, as will be demonstrated further herein, semantic aspect ${ }^{12}$. In Greek literature structural formulas introducing both orationes were often omitted. To such an extent, that it is sometimes difficult to recognise the transition between one and the other. Linguists define such a situation as "mixed question"13. In the modern IE languages, including Polish, this is a rare phenomenon and the designating formulas are well-formed. A different situation, one that occurs with ancient Greek, results from a long period of coexistence between the worlds of spoken and written messages, the listener and reader, orator and writer etc. Hence the widespread conviction of axiological supremacy of orality over literacy. This fact of primary importance must be remembered while reading ancient and Byzantine authors.

For the purposes of this paper, speeches have been divided into separate categories. The basic criterion for their belonging to either category is the person (diplomat, emperor, commander) or group (soldiers, representatives of demes). The specified group includes speeches that are significant for the text's structure. In most cases their function is to introduce the reader into a new issue, they act as liaisons between larger narrative sections. They will be discussed in their individual categories. Finally, we will try to answer the question about the actual role of speeches in the work of Theophylact Simocatta, i.e. how the tension between formal measures and the author's objectives was formed.

Finally, one should stress the fact that Historiae does not contain one of the most important ancient speeches: epitafios logos, its example in the History of the Peloponnesian War has been widely and always regarded as top literary achievement of Thucydides ${ }^{14}$.

1. Military speeches. The first category to be discussed includes speeches made before combat and speeches directed at armies as a general public. There are nine such speeches in the text, which is not anything surprising considering the fact that Theophylact's attention was drawn to military conflicts with

${ }^{12}$ Although the bibliography concerning this topic in classical literature (cf. V. Bers, Speech in Speech. Studies in Incorporated Oratio Recta in Attic Drama and Oratory, London - New York 1997 ) is extensive, there are practically no studies that would analyse in-depth the oratio recta in Byzantine historiography.

${ }^{13}$ Cf. E. Maier, Reported Speech in the Transition from Orality to Literacy, "Glotta" 91 (2015) 152-170. One must admit that Theophylact's prose is relatively clear on that level, however it is not absolutely a rule.

${ }^{14}$ Cf. O.P. Landmann, Die Totenrede des Thukidydes, Bern 1945; H. Flashar, Der Epitaphios des Pericles. Seine Funktion im Geschichtswerk des Thukydides, Heidelberg 1969; K. Gaiser, Das Staatsmodell des Thukydides. Zur Rede des Perikles f. die Gefallenen, Heidelberg 1975; J. Ziółkowski, Thucydides and the Tradition of Funeral Speeches at Athens, New York 1981; N. Loraux, The Invention of Athens, The Funeral Oration in the Classical City, Harvard 1986; R. Turasiewicz, Pericles' 'Funeral Oration' and Its Interpretation, "Eos" 83 (1995) 33-41. 
Avars and Slavs in the Balkans and with Persia in the East. In 1993 Mogens Hansen ${ }^{15}$ questioned the existence of written speeches actually delivered by ancient commanders on the day of battle. In his brilliant analysis he claimed that oratorical displays before the army were a literary fiction created by Thucydides ${ }^{16}$ and then continued by further generations of historians as far as modern times ${ }^{17}$. This thesis is, however, too far-fetched. Even if the commanders did not speak before the army front-line just before the battle, we know that the speeches directed at soldiers before major events actually took place ${ }^{18}$. Also Theophylact, when presenting similar circumstances, used the literary topos he knew so well, but he did it skilfully and, which should be appreciated, not at every available opportunity.

While keeping the order aligned with Theophylact's narrative, one can indicate the following speeches to the army: strategos Philippicus to the army before the battle of Solachon ${ }^{19}$, anonymous chiliarch to the army and Comentiolus after the defeat of the forces of Castus ${ }^{20}$, veteran in the Comentiolus' army in response to the speech of the chiliarch ${ }^{21}$, army to Priscus during the mutiny following the deposition of Philippicus and reduction of soldier's pay ${ }^{22}$, Aristobulus' addressing the army following the mutiny ${ }^{23}$, strategos Justinian to the army before the battle of Daraa ${ }^{24}$, speech made to the soldiers before the battle with Persian rebels led by Bahram ${ }^{25}$, Priscus after the battle with Slavs, on the

${ }^{15}$ Cf. H.M. Hansen, The Battle Exhortation in Ancient Historiography. Fact or Fiction?, "Historia" 42 (1993) 161-180. Hansen's work was criticised by, for example, A. Goldsworthy, The Roman Army at War 100 BC-AD 200, New York 1996, 146-147, who pointed out a number of interesting speeches to a large group of soldiers.

${ }^{16}$ Cf. Thucydides, Bellum Peloponnesiacum IV 9-10. One of the more interesting speeches in Thucydides' work was the Demosthenes' speech at Pylos. The events from Pylos were discussed in detail by J. Roisman, The General Demosthenes and his Use of Military Surprise, Stuttgart 1993, 33-42. Later ancient literature demonstrated a varying approach to this issue. The fictional speech by Alexander the Great to the commanders before the conquest of Tyre, included in the work of Arrian (IV 17) is an excellent example thereof. It differs considerably from the topos set out by Thucydides, as Alexander did not address his army directly, but conveyed his words through officers who then delivered them to their subordinates, see Arrian, The Anabasis of Alexander, transl. H. GesztoftGasztold, Wrocław 2004, 91-92. More on the rhetoric used for military purposes in ancient times can be found in the work of A.В. Махлаюk, Ропь ораторского искусства полководиа в идеологии и практике военного пидерства в древнем Риме, "Вестник Древней Истории” 248 (2004) 31-48.

${ }^{17}$ Cf. Hansen, The Battle Exhortation, p. 171.

${ }^{18} \mathrm{Cf}$. Ł. Różycki, $\Sigma \tau \rho \alpha \tau о \kappa \hat{\rho} \rho v \xi$ and $\kappa \alpha \nu \tau \alpha \dot{\tau} \tau \omega \rho$ vs the presence of speeches before a battle in the early Byzantine military treatises, "De Re Militari” 2 (2015) 21-33.

${ }^{19} \mathrm{Cf}$. Theophylactus Simocatta, Historiae II 3, 4-7.

${ }^{20} \mathrm{Cf}$. ibidem II 13, 2-14.

${ }^{21}$ Cf. ibidem II 14, 1-12.

${ }^{22} \mathrm{Cf}$. ibidem III 1,10 .

${ }^{23} \mathrm{Cf}$. ibidem III 3, 10 .

${ }^{24} \mathrm{Cf}$. ibidem III 13,1 . This speech will be discussed while deliberating on the imperial speeches due to the fact that it forms a compositional whole with the speech of Justin II.

${ }^{25} \mathrm{Cf}$. ibidem V 4, 5-15. 
division of spoils ${ }^{26}$, Peter to the mutinous army ${ }^{27}$. Most of these speeches are significant for the composition of texts or the narrative itself, it needs to be stressed that these are not speeches resulting only from the ancient literary topos.

The first speech to the army was the address by Philippicus before the battle of Solachon in $586 \mathrm{AD}^{28}$. At the very beginning one encounters an extraordinary situation. Theophylact presented all circumstances of the leader's oration, describing in detail even the battlefield theatre, i.e. a local bishop showing a holy picture around and a fully ritual behaviour of the leader who lamented over the upcoming conflict and bloodshed. This was all in line with the "performance" convention that was natural then ${ }^{29}$ : the leader comes before the army, addresses the troops readying for mortal combat and the battle begins. Theophylact, however, deviated from the classical composition of the speech which he later attributed to the leader. Instead, he briefly described the impression the speech made on the soldiers:

"Then, having approached the middle of the troops and shedding many tears on the works of war, he addressed the army with words of consolation. The nature of the speech proved effective both in encouraging the zealous to make even more effort and to foster enthusiasm with the lazy and slothful ones"30.

It seems understandable at this point that the author abandoned the idea to include the speech in its entirety and in oratio recta. The conflict with Persia had been presented earlier and the oration of Philippicus would only be an opportunity for literary displays, which would make the account unnecessarily trivial. Simocatta stressed, however, that the speech existed and that it succeeded in achieving the planned purpose and uplifted the soldiers' morale. This shows particular focus made on evaluation. This is fully compliant with the traditional role of rhetoric that vis persuadendi is. The power of words should bring the listening soldiers to metanoia and in this case it proved successful. By giving up the military details, the historian achieved even stronger ethical impact: in the juxtaposition of antonyms $\tau \hat{\omega} \nu \mu \dot{\varepsilon} \nu \sigma \pi 0 v \delta \alpha i \omega v-\tau \hat{\omega} v$

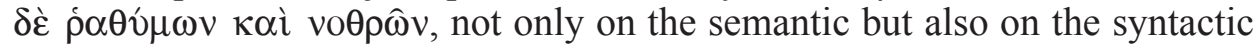
level: $\tau \hat{\omega} \nu \mu \grave{\varepsilon} \nu-\tau \hat{\omega} \nu \delta \dot{\varepsilon}$.

The situation with the next speech, the address by the tribune before Comentiolus' army front-line, is very different. Namely, contrary to the previous

\footnotetext{
${ }^{26}$ Cf. ibidem VI 7, 10-16.

${ }^{27}$ Cf. ibidem VIII 7, $2-4$.

${ }^{28}$ Cf. A. Kotłowska - Ł. Różycki, The Battle of Solachon of 586 in light of the works of Theophylact Simocatta and Theophanes Confessor (Homologetes), "Travaux et Mémoires" 19 (2015) 315-327; J. Haldon, The Byzantine wars: battles and campaigns of the Byzantine era, Charleston 2001, 54.

${ }^{29}$ Cf. Greek Ritual Poetics, ed. D. Yatromanolakis - P. Roilos, Cambridge (Mass.) 2005, or in a more general approach R. Bauman, Verbal Art as Performance, "American Anthropologist" 77 (1975) fasc. 2, 290-311.

${ }^{30}$ Theophylactus Simocatta, Historiae II 2, 6-7, ed. de Boor - Wirth, p. 73, transl. by Authors.
} 
scene of universal sense, the historical context is very important here ${ }^{31}$. In 587 $\mathrm{AD}^{32}$ Comentiolus was waging war against the Avars. After initial successes the Roman army found itself in a difficult situation following the defeat of the separate group of Castus. The strategist, after the defeat of the best troops, convened a council of war and then requested the army to continue with the campaign against the Avars. The idea of further fight after the Castus' elite troop had been lost was not to the liking of one of the archons in the rank of chiliarch. During the gathering of soldiers he made a public appearance and criticised the willingness to fight on, suggesting retreat ${ }^{33}$. This address is evidently artificial: it is an artistic progymnasma, a rhetoric exercise aimed at pro et contra argumentation, i.e. anaskeue and kataskeue. The artistry of the address, which was far from military jargon, may be demonstrated by the use of phrase concerning "the birth of words" which is an obvious reference to the Platonic language of the "maieutics of thoughts" (Teajtet, 148e-151d). The manner in which Theophylact referred to the presented argumentation is very significant. The completion of the oration by the chiliarch was formulated as follows: "he spat reprehensible words" ${ }^{34}$. It is the same type of move as the aforementioned demonstrative lament of the leader, wherein the body language complements and authenticates the spoken word and, concurrently, in this case it bears emotional qualities that show the author's attitude towards the speaker.

Meanwhile, an old veteran who was the next speaker joined the polemics with the chiliarch ${ }^{35}$. He evoked the old valour of Romans, motivated and encouraged the army to fight on. He did so in an equally elaborate manner as his predecessor: he used erudite numerous exempla to define the true bravery, the genuine $\alpha \rho \varepsilon \tau \eta$. All this was illustrated with a quote from Gorgias (482c). Both speeches are inseparably interconnected, they are so to speak two sides of the mirror, therefore they should not be analysed separately. Through the words of the first speaker Theophylact presented the breakdown of morale in the Roman army after Castus' troops had been defeated even when the leaders, faced with the enemy, were ready to flee. Thanks to the archon's orations, the reader learned that the army was not able to continue the fight and the defeat of the cavalry on the other bank of the river was perceived a bad omen. From

${ }^{31}$ Cf. M. Whitby, The Emperor Maurice and his Historian Theophylact Simocatta on Persian and Balkan Warfare, Oxford 1988.

${ }^{32}$ The issue of chronology in Theophylactus' work was discussed by such academics as: J. Bury, The Chronology of Theophylaktos Simokatta, "The English Historical Review" 3 (1888) 310-315; N. Lewis, On the Chronology of the emperor Maurice, "American Journal of Philology" 60 (1939) 414-421; G. Labuda, La Chronologie des guerres de Byzance contre les Avares et les Slaves à la fin du VI siècle, "Byzantinoslavica" 11 (1954) 167-173.

${ }^{33}$ Cf. Theophylactus Simocatta, Historiae II 13, 2-14.

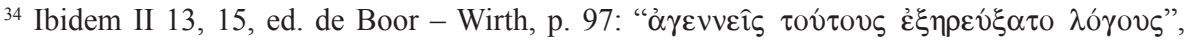
transl. by Authors.

${ }^{35} \mathrm{Cf}$. ibidem II 14, 1-12. 
the military point of view, losing the best cavalry units posed a major difficulty in combating the Avars but was not tantamount to defeat. It was, on the other hand, stylised to seem credible and started with the following words: "[...] but we will not be scared, like children, with sophistry" ${ }^{36}$. The speech was in fact equally artificial; the words of the old veteran bring to mind the great heroes of the Roman past. He evoked the courage of Romans and the allure and difficulties of a soldier's life and called to fight. Thus Theophylact stressed that despite problems with the army's morale, some soldiers intended to continue the fight which was in accordance with the ethos of military tradition. Thanks to juxtaposing both perspectives, Theophylact first presented the actually bad situation the Roman army found itself in and the undermined morale of the troops who did not face the opponent yet and then, through an anonymous solder, he presented the desired state to be achieved.

The next two speeches are very similar. Theophylact used an exchange between the mutinous Roman army and Priscus to show the situation in the Eastern formation acting against Persians ${ }^{37}$. An interesting thing was to let the community speak; the army responded to Priscus as follows:

"Order among the troops has broken as the army seems to be deprived of command" $"$.

Priscus' response to the soldiers' statement was a cowardly one and Simocatta made a sarcastic, though colourful comment on it:

"Priscus, the commander, drew sweat and scared so much that he lost all ability to make decisions" 39 .

The use of the ancient and respectable term of $\pi \circ \lambda \varepsilon \dot{\varepsilon} \mu \alpha \rho \chi \varsigma_{\zeta}$ to refer to the commander is clearly ironic. The speech was delivered by the army as a community and such a solution was supposed to underline the unanimity and determination of the soldiers during their negotiations with Priscus, a leader not accepted by the soldiers, who brought imperial orders to lower their pay ${ }^{40}$. There are a few more speeches in the text referring to the events of $588 \mathrm{AD}$ in the East. Having found shelter in Edessa (today's Urfa), Priscus received the envoys of the mutinous army whom he had to convince, using oratory skills,

\footnotetext{
${ }^{36}$ Ibidem II 14, 1, ed. de Boor - Wirth, p. 97, transl. by Authors.

${ }^{37}$ Cf. I.V. Krivouchine, La révolte pres de Monocarton vue par Évagre, Théophylacte Simocatta et Théophane, "Byzantion" 63 (1993) 154-173.

${ }^{38}$ Theophylactus Simocatta, Historiae III 1, 10, ed. de Boor - Wirth, p. 111, transl. by Authors.

${ }^{39}$ Ibidem III 1, 10, ed. de Boor - Wirth, p. 111, transl. by Authors.

${ }^{40}$ Cf. Ł. Różycki, Próby reformy finansów armii rzymskiej w czasach Maurycjusza (582-602), in: Ekonomia a wojna studia i szkice, red. M. Franz, Torun 2011, 47-57. Despite considerable spoils the financed were imbalanced. A. Lee, War in Late Antiquity. A Social History, Oxford 2007, 101-102.
} 
that he had not participated in any unjustness ${ }^{41}$. Then, Aristobulus ${ }^{42}$, an envoy sent by Maurice, convinced the army, with his speeches and gifts, to join the military action.

The purpose of Dometianus' ${ }^{\prime 3}$ speech addressed to Roman troops upon entering Persian territory near Daraa was to stress the importance and rightness of Roman actions against Bahram's tyranny ${ }^{44}$. Theophylact, through the Roman strategos, wanted to confirm the reader in their conviction of the legitimacy of Roman intervention in Persia.

"Be therefore strong in spirit while loving a change in fate. Here comes the Babylonian king, enslaved to the Persian misery and by giving himself to us he has given us the power, trusting in religious piety. The Persians despise the tyrant. Bahram has assumed the altar of godlessness since he does not come from a royal family. As he made hybris the foundation of his power, he will quickly be overthrown. There is no violence without conflict" ${ }^{\prime 4}$.

The speech was also supposed to stress the fighting spirit of the Romans and their eagerness for combat:

"Do not let your back be wounded as it will not see the victories. Be united in spirit and body, sharing the effort but not cowardice. Expelled be he who fails to accept what comes with danger! Even in death, reach for victory. Triumph is won among wounds and shots. Indolence brings nothing praiseworthy and there is nothing sweeter than death in battle"46.

The speech by Dometianus complemented the Hormisdas' oration which was an introduction to the conflict with the usurper and an accusatory oration of Bindoes $^{47}$ as well as later letters of Khosrow to Maurice, and its main purpose was to depict the moods of the army which, uplifted by religion, was supposed to defeat Bahram's tyranny.

${ }^{41}$ Cf. Theophylactus Simocatta, Historiae III 3, 3.

${ }^{42}$ Cf. R. Janin, Constantinople byzantine. Développement urbain et Répertoire topographique, Paris 1951, 310. The palace of Antioch (domus Antiochi) which Aristobulus was a curator of, was located next to the Hippodrome. Aristobulus (apo eparchon and antigrafeus) is also known for the meeting with Golinduch, when he visited her in prison as a papal envoy to Persia (ak. 9 vitae Golinduch, ed. Peeters).

${ }^{43}$ Cf. Theophylactus Simocatta, Historiae V 4, 5-15.

${ }^{44}$ Cf. I.V. Krivushin, Theophylact Simocatta's Conception of Political Conflicts, "Byzantinische Forschungen" 19 (1993) 171-183. Theophylact's position regarding tyranny was emotional and resulted partly from political doctrine dating back to the times of Heraclius. The author himself was often referring to the opposition of stasis and tyranny.

${ }^{45}$ Theophylactus Simocatta, Historiae V 4, 12, ed. de Boor - Wirth, p. 196, transl. by Authors.

${ }^{46} \mathrm{Cf}$. the famous verse of Horace (Odes 3): "dulce et decorum est pro patria mori" (ibidem V 4, 8-10, ed. de Boor - Wirth, p. 195, transl. by Authors).

${ }^{47}$ Cf. ibidem IV 4, 1-16; IV 5, 2-12. 
Another speech made by the leader to the army was recorded after the victory over Slavs in $593 \mathrm{AD}$. The victory over barbarians gave the Roman army abundant spoils but also caused the commanding Priscus some diplomatic and disciplinary problems. These problems were focused on the spoils of the Roman army, who gained considerable wealth from Ardagast's ${ }^{48}$ Slavs. As Theophylact himself admitted, the Slav hordes ( $\tau \dot{\alpha} \tau \hat{\omega} \nu \Sigma \kappa \lambda \alpha v \eta v \hat{\omega} \nu \pi \lambda \eta \dot{\theta} \theta$ ó $\pi \delta \delta \eta \mu \alpha$ : plethos - "crowd", has a pejorative connotation in Greek) were for some time crossing the Danube to loot Roman provinces ${ }^{49}$, now, thanks to the actions of the Roman army the Slavs were surprised on their own territory and defeated without much effort. Gaining abundant spoils must have been a godsend gift for professional soldiers, as it could keep their families wealthy for years to come, therefore their mutiny, triggered by the declarations of Priscus, the leader, that a significant portion of the spoils should go to the emperor and his family, should not come as a surprise. The soldiers were saddened by this news and the army was ready to mutiny to protect their spoils but owing to a shrewd oration of Priscus the moods changed dramatically. While commenting on the entire event, Theophylact mentioned the power of the speech:

"The strategos still was carried by the waves of his own words, Romansounding atticism of Themistocles, as the crowd broke with applause and the mood changed from hostile to favourable, lampoon to praise, scorn to cordiality. This is how everything changed. One should recognise the power of the speech: taming the nature, introducing necessary laws, shaping the mindset, changing destiny and, in general, reforming everything, moulding and encouraging obedience"so.

Upon learning of winning riches, which must have been truly royal, also the Avar khagan intervened claiming his share. Both conflicts were prevented thanks to the abilities of the strategos, and the skilfully handled talks played a key role.

A speech connected directly with the army was the one delivered by Peter, an imperial brother commanding the troop in the Balkans, after having received imperial orders to spend the winter on the barbarian bank of the

${ }^{48}$ Discussion is pending regarding the etymology of the name. Advocates of the Slav origin include: P. Szafarzyk, Stowiańskie Starożytności, Poznań 1844, 459: Radgost; P. Kretschmer, Die slavische Vertretung von indogerm. o., "Archiv für Slavische Philologie" 27 (1905) 228-240. Followed, although tentatively, the authors of Stownik Starożytności Słowiańskich, ed. S. Urbańczyk - M. Plezia, t. 1, Wrocław - Warszawa - Kraków 1961, 46; G.Y. Shevelov, A Prehistory of Slavic, Heidelberg 1964, 395. Opponents include M. Vasmer, Die Slaven in Griechenland, Berlin 1941, 290; V. Machek, Etymologický slovník jazyka českého, Praha 1968², 504-505; E. Nieminen, Über ein vermutliches urslawisches Lehnwort im Ostseefinnischen, "Die Welt der Slawen" 3 (1958) 101123. Iranian origin.

${ }^{49}$ Cf. Theophylactus Simocatta, Historiae VI 7, 10-16.

${ }^{50}$ Ibidem VI 8, 1-3, ed. de Boor - Wirth, p. 234, transl. by Authors. 
Danube $^{51}$. The words of the strategos, who feared for the emperor's life, were meant for Guduis. The speech was prophetic and strongly archaised, just to mention Peter's words:

"Poisoned with such an emotion [i.e. greed], the emperor «may soon lose his life», just to embellish my phrase with the words of Homer's tragedy. This day marked the beginning of great evil for Romans. This I know and I suffer"s2.

The verse quoted is from A 205. Not accidentally this is a part of Achilles' threat made to Agamemnon Atreides, spoken to Athena. Thus, Theophylact wants to subtly suggest that if Maurice fails to wander off the erroneous path, he will share the fate of Atreus' son, he will be killed by his kin. This may be interpreted only as an allusion to Phokas' mutiny caused by clumsy policy of the emperor with regard to the army. The next day Peter faced the army and presented the emperor's wish. The leaders of units refused to follow the order and the soldiers rebelled, choosing Phokas as their representative, which marked the downfall of Maurice. Theophylact presented his opinion on these events in Peter's speech, stressing that it all began with one wrong order, the unintended consequences of which brought great misery upon the Empire.

The speeches addressed at soldiers are mostly topological with high content of semantics focused on evaluation. This, obviously, does not exclude their conscious use to realistically stress the gravity of the situation (speech before the battle of Solachon) or conveying own opinion of the events (veteran's speech). The specific situation and goals set by the author require at the same time nuancing the application of rhetorical measures. An excellent example is the Philippicus' speech before the battle of Solachon in 586 AD. To slavishly follow the ancient topos, Theophylact should have presented the heroic leader spurring his soldiers to fight with their eternal adversary by sophisticated oration; this would be at the same time a great opportunity to show off his own rhetorical skill or communicate his personal views regarding Persians. Simocatta, however, abandoned all that, making do with just a short description of the impression his speech made on the soldiers. To understand this measure, one needs to look at the text as a whole. Theophylact's opinion of Persians is expressed already in book one, when discussing the speech of the Persian ambassador to Romans; he deemed it redundant and technically primitive to repeat this information. The historian focused therefore on the consequences of the oration, thus gaining a stronger emotional effect. This was skilful and fully compliant with tradition wherein the speech before the battle must take place, and concurrently, it saved the reader from feeling weary of repetition. Other speeches addressed to soldiers or their responses to their leaders are also well-grounded, this time in the social aspect. All situations wherein the military is given the voice stress the unanimity of the soldiers' opinions and define this group as a community.

\footnotetext{
${ }^{51}$ Cf. ibidem VIII 7, 2-4.

${ }^{52}$ Ibidem VIII 7, 3-4, ed. de Boor - Wirth, p. 295-296, transl. by Authors.
} 
On the other hand, the speeches made by the commanders to their subordinates occur only in significant situations, usually crises. This category should include both speeches made by Priscus with which he intended to bring order to the mutinous army, and Peter's monologue. In each of these situations, Theophylact stressed the dramatic nature of the event using direct speech (oratio recta) to smuggle his opinion and demonstrate his own literary artistry (at one point he is quite brutal when reminiscing Themistocles directly $)^{53}$. The position of military speeches in the text was therefore well-thought through and Theophylact used them sparingly and included only in situations of considerable importance (a major battle) or critical (army's mutiny).

2. Envoy speeches. Speeches of Roman diplomats and their adversaries from the other side of the limes is the most important category in the entire work. The very fact that some of the official correspondence between Khosrow and Maurice has been woven by Theophylact into the text as speeches is extremely important. And these are not the only fragments where the author announced he would be quoting verbatim without embellishing or amending anything. Ambassadors' speeches, in particular speeches from Book 1, are also hugely significant for the entire text's composition.

The first envoy speech was that of Comentiolus delivered before the khagan of Avars ${ }^{54}$. All the narration about this event is hugely emotional. Theophylact used Comentiolus' mission to present the nature of the Avars. The barbarians were painted in dark colours by the author, as bandits with no respect for any sanctities, including the ambassador's bodily integrity, about to betray and break their promise at every opportunity ${ }^{55}$. Simocatta made a double use of this speech for his purposes. Firstly, already in the early pages of the Historiae he introduced the readers to one of the Empire's key adversaries, showing the barbarians as a true plague that afflicted the peaceful Balkans. This picture was false but consistent with the then Roman convictions that presented the Avars virtually in the same light ${ }^{56}$. Strong emotional character of this part of the text is also not negligible. Describing the meanness of the khagan of Avars to the Roman diplomat and presenting the nomadic barbarians as devoid of honour

${ }^{53}$ This category should also include the speech delivered by Dometianus.

${ }^{54}$ Cf. Theophylactus Simocatta, Historiae I 5, 1-16.

${ }^{55}$ Cf. Mauricius, Ars militaris XI 2 (ed. G.T. Dennis: Das Strategikon des Maurikios, transl. E. Gamillscheg, Wien 1981). Extensive accounts on Avars can be found in: A. Avenarius, Die Awaren in Europa, Bratislava 1974; W. Pohl, Die Awaren. Ein Steppenvolk in Mitteleuropa 567-822 n. Chr., München 1988; W.H. Fritze, Zur Bedeutung der Awaren f. d. Slavische Ausdehnungsbewegung im frühen Mittelater, „Zeitschrift für Ostforschung” 28 (1979) 498-545. Roman-Avar relations were presented by B. Zástěrová, Les Avares et les Slaves dans la Tactique de Maurice, Praha 1971,

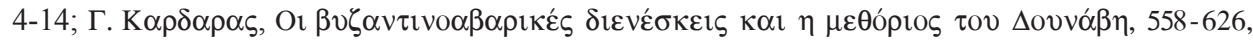

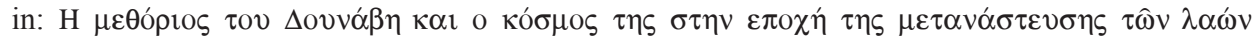

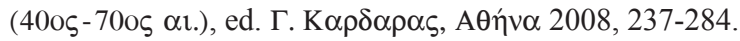

${ }^{56} \mathrm{Cf}$. Mauricius, Ars militaris XI 2. 
that the civilised peoples had, Theophylact Simocatta also clearly emphasised his own attitude towards the barbarians. It was a most negative attitude which was probably due the fact that at the time when the work was being written, the Avars were still an immense threat to the Empire in the Balkans ${ }^{57}$.

Another diplomacy-related speech, found already in the beginning of book one, was the speech of a Persian diplomat Mebodes demanding the Romans to cease fire and pay contributions for years of destructive war ${ }^{58}$. Theophylact used this speech as an introduction to the history of Persian-Roman war. As the conflict had continued since the time of Justin II $^{59}$, Theophylact did not intend to present the history from the very beginning. Mebodes' speech composed by the author was to introduce the reader into key issues of the war, indicate grounds for its outbreak, and emphasise the recent Roman victories. Confronting the speech with the first oration of a Roman diplomat in which Comentiolus faced the khagan of the Avars, interesting conclusions can be drawn. Firstly, the narration is reversed, it is not the Roman diplomat speaking, the floor is given over to Satrap Mebodes. This fact alone permits a statement that the two great adversaries of the Empire in the last two decades of the $6^{\text {th }}$ century had a different status in the eyes of Theophylact. The author hated the Avars and did not leave any doubt about it in the case of Comentiolus' speech and description of its consequences, while the Persians were presented differently The Satrap was presented as an equal partner, currently an enemy but insisting that the Romans and the Persians would return to peaceful and amicable relationships as soon as the horns of war stop being blown. Persia, in spite of being the Empire's traditional rival, was pictured as the second civilised power ensuring global stability ${ }^{60}$. It was emphasised in the foreword to the envoy speech: "The Persians sent an envoy to end the war worthily" ${ }^{1}$. The adverb worthily - $\dot{\varepsilon} v \delta o ́ \xi \omega \varsigma$ confirms the special importance of the political and ethical responsibility of the Sassanid elite and the Constantinople government's approval of it. This conviction has been anything but extraordinary in the Roman geopolitical reflections as early as since the Augustian era $^{62}$. Nevertheless, Theophylact could have expressed it in a more elliptical or critical manner. The evident approval found throughout the speech, however, allows us to form a hypothesis on the presumed dating of the entire work. Both countries restarted the war immediately after the death of Emperor Maurice (602 AD) and continued it for most of Emperor Heraclius' reign, leading the Empire to the

${ }^{57}$ Cf. W.E. Kaegi, Heraclius, Emperor of Byzantium, Cambridge 2007, 58-99.

${ }^{58} \mathrm{Cf}$. Theophylactus Simocatta, Historiae I 15, 3-10.

${ }^{59} \mathrm{Cf}$. ibidem III 11, 8. The history of Persian-Roman wars deserved a separate mention by Theophylactus.

${ }^{60}$ Cf. B. Dignas - E. Winter, Rome and Persia In Late Antiquity Neighbours and Rivals, Cambridge 2007, 323-342.

${ }^{61}$ Theophylactus Simocatta, Historiae I 15, 1, ed. de Boor - Wirth, p. 68, transl. by Authors.

${ }^{62}$ Cf. Res Gestae Divi Augusti 31-33. 
edge of the abyss ${ }^{63}$. Theophylact was closely tied to Heraclius, it is, therefore, hard to imagine that the author would present an evidently positive picture of the nation at war with his country, threatening its very existence, and dominating Heraclius' politics for many years. If, therefore, Persians are presented in a positive light ${ }^{64}$ and Theophylact clearly emphasises that enemies may easily become friends, it can be concluded that Historiae were written after the end of Heraclius' war with the Persians, that is after $628 \mathrm{AD}^{65}$. Obviously, it is just a circumstantial evidence but is an interesting contribution to further discussion on the date of the entire work ${ }^{66}$.

Another diplomatic speech is found in book two, following the battle of Solachon. Victorious Roman troops entered Arzanene to cross the Persian communication routes and eliminate the fortified positions securing the enemy's hold of the province ${ }^{67}$. Defeat of the Persian army made some of the local population choose to leave their previous protectors and shift their loyalties to the Romans. The triumphant Philippicus was to receive a delegation of the Persian lords who were to swear fealty to him, hand the province over to him, and indicate the best locations to build fortifications ${ }^{68}$. Theophylact emphasises here the personal initiative of those persons by writing that they were acting on their own ( $\alpha v \tau \circ \mu \alpha \tau i \zeta o v \sigma \imath)^{69}$. The lords were two brothers with Armenian names of Maruthas and Jobios, and Theophylact openly refers to them as Arzanene's leaders ${ }^{70}$. In doing so, he uses dualis, indicating unanimity of the brothers ${ }^{71}$. Philippicus received the envoys kindly and was glad to follow their advices. Unfortunately, soon afterwards the previously victorious Roman army was forced to retreat in chaos, which lost most of the winnings of the

${ }^{63}$ Cf. J. Howard-Johnston, Witnesses to a World In Crisis Historians and Histories of the Middle East in the Seventh Century, Oxford 2011.

${ }^{64}$ Cf. J. Polacek, Heraclius and the Persians in 622, "Bizantinistica" 10 (2008) 105-124. On redefinition of mutual relations following the end of warfare.

${ }^{65}$ Cf. Theophylactus Simocatta, Historiae V 15, 5-7. Note also that the last event recorded by Theophylactus was the suggested death of Shahenshah Khosrow in 628 AD.

${ }^{66} \mathrm{Cf}$. Whitby, The Emperor Maurice, 40. Whitby puts forward a similar opinion and states that the work was finished after $628 \mathrm{AD}$.

${ }^{67}$ Cf. S. Michell, Byzantine Anzitene, in: East Rome, Sasanian Persia and the End of Antiquity, ed. J. Howard-Johnston, Farnham 2006, 239. Arzanene is located in the North-Western edge of Armenia, closed by Taurus Mountains from the North, and by Euphrates from the South. Note also the fragment on Arzanene in Die Ostgrenze des Byzantinischen Reches, E. Honigmann, Die Ostgrenze des Byzantinischen Reches von 363 bis 1071 nach griechischen, arabischen, syrischen und armenischen Quellen, Bruxelles 1935, 28-30.

${ }^{68}$ Cf. Mauricius, Ars militaris X 4.

${ }^{69} \mathrm{Cf}$. Theophylactus Simocatta, Historiae II 7, 6.

${ }^{70}$ Cf. J. Preiser-Kapeller, Erdumn, ucht, carayut'iwn Armenian Aristocrats as Diplomatic Partners of Eastern Roman Emperors 387-884, “Armenian Review” 52 (2010) 139-215.

${ }^{71}$ Cf. Theophylactus Simocatta, Historiae II 7, 7. It should be noted that dualis was no longer used in colloquial speech and is relatively rare even in high-register literary texts and always carries an additional semantic meaning. 
battle of Solachon. The role of this speech, albeit brief ${ }^{72}$, and the importance of the entire digression concerning the envoys remains a mystery and should be interpreted in several aspects. After the peace treaty of $591 \mathrm{AD}$, the province of Arzanene became a part of the Roman Empire. It was a disputed land, for years under control of the Persians, which is why it can be assumed that the population was not friendly towards the Empire ${ }^{73}$. Delegation of lords to Philippicus was an evident betrayal and maybe this was how Theophylact tried to justify the subsequent takeover of control over the entire province, by explaining the circumstances with a suggestion of "free will" ( $\alpha v \tau \circ \mu \alpha \tau i \zeta o v \sigma \imath)$ of the main characters. Were the Historiae written after $628 \mathrm{AD}$, as suggested above, another political reason can be found. After the fights between Rome and Persia ended in $628 \mathrm{AD}^{74}$, the Empire returned to its boundaries following the peace treaty of $591 \mathrm{AD}^{75}$, and thus Arzanene came again under a formal control of Rome. It is possible that by including the speech of the lords Theophylact wished to justify the re-annexation of the province, showing that the Romans have held the right to it for more than thirty years and that at least some of the civil population had sworn fealty to Rome many years ago.

There is one more possible explanation of the above episode, based on strictly personal likes and dislikes of the author. The campaign was led by Philippicus - a strategist not much liked by Theophylact ${ }^{76}$ according to contemporary historians. It cannot be excluded, therefore, that Theophylact used this speech in order to prove how big a success the campaign might have been had not it been for Philippicus' actions which resulted in the Romans' retreat from Arzanene the same year. It is true that Theophylact diminished the actual importance and achievements of Philippicus, and this prejudice was related to his deputy, father to Emperor Heraclius, whose achievements would be favoured at the chief commander's cost.

The role of envoy speeches is important in Theophylact's work. In the diplomats' mouths Theophylact put the descriptions of political background, explaining the truces and court games. Notably, the most important speeches of diplomats are found in book one where they are an introduction into current foreign relationships of the Empire and an outline of the historical background. The next political speech of similar importance is found as late as in book four ${ }^{77}$. The importance of this speech is exactly the same as of the two previous ones in book one. Theophylact uses it to picture the background and introduce

${ }^{72}$ Cf. ibidem II 7, 9.

${ }^{73}$ Cf. ibidem II 1, 1-3. The last friendly point was Mount Izla. See: D. Johanson, Monks of Mount Izla, Origins of Monasticism In Upper Mesopotamia In the 4th-6th centuries Translations and Analysis from previously unpublished Syriac Manuscripts, Washington 2004, 6-7.

${ }^{74}$ Cf. Dignas - Winter, Rome and Persia, p. 148-151. For terms of peace in 628 AD.

${ }^{75}$ Ibidem.

${ }^{76}$ Cf. Whitby, The Emperor Maurice, p. 282-284.

${ }^{77}$ Cf. Theophylactus Simocatta, Historiae IV 4, 1-16; IV 5, 2-12. 
new narration. Book four focuses mainly on the situation at the Persian court. The first of the speeches is made by the overthrown Shahenshah Hormisdas (or Hormuzd IV, 579-590 AD) before Persian notables; the second one is the reply to Hormisdas give by Bindoes. In the first of these speeches, Theophylact introduces the reader into the meanders of the Persian court, presenting the key elements of Hormisdas's internal politics. Although the speech is structured as a defendant's pleadings before a court, the reader does not have any difficulty in recognising Theophylact's dislike of Hormisdas ${ }^{78}$. This impression was supposed to be enhanced by the accusatory speech made by Bindoes who skillfully refuted the arguments of his dethroned ruler, proving that the successes achieved during his reign should be attributed to valour of the Persians and not the abilities of the king of kings. Then, Bindoes presents the internal situation emphasising Hormisdas's tyrannical inclinations, numerous murders and trial of political adversaries, finally bringing forth the damage done to Khosrow when dividing the rule of the country. Khosrow in this speech is pictured as a brave and smart youth to whom the throne and the Persian sceptre were due by birth and because of his personal characteristics. This way Theophylact tackles two separate issues, and the seed was sown already in book one in the speech of the Persian satrap. It was not Persia that was Rome's adversary who led to long-lasting war, the fault was with the tyrannical rule of Hormisdas. Persia, as Mebodes ${ }^{79}$ says, could become a friend of Rome but it was not possible until the Shahenshah was a ruler oppressing his noble citizens. Simocatta thus divided the ruler and his state, laying down intellectual ground for interpretation of the events to follow. Rome's aid to Khosrow could seem strange to the readers, in particular in the first half of the $6^{\text {th }}$ century when the two countries were involved in mortal combat. Theophylact masterfully presented Maurice's policy by exposing only some of its features. Persia found itself at a turning point: Hormisdas who was supposed to be the source of evil has been overthrown while a young and inexperienced King Khosrow at the time had to face a mutiny of notables led by the influential Bahram (589-591 AD $)^{80}$. Thus, the Emperor was intervening into internal affairs of Persia in good cause, to restore the legitimate rule and dynasty, seeing the young king as the hope for ending the war. It would be difficult not to look for similarities. In 610 , the future Emperor Heraclius along his father officially challenged the tyranny of Phocas characterised by murders and trials of political adversaries. Vengeance

${ }^{78}$ This does not mean that Theophylact did not empathise with the family of the dethroned ruler (although he named the ruler a tyrant paying no heed to his people's voice).

${ }^{79} \mathrm{Cf}$. ibidem I 15, 3-10.

${ }^{80}$ Cf. K. Czeglédy, Bahram Čobin and the Persian Apocalyptic Literature, "Acta Orientalnia Academiae Scientiarum Hungaricae" 8 (1958) fasc. 1, 21-43. Theophylactus had no understanding of the true, deep reasons for the speech of Bahram Čobin being the deep-running divisions within the Persian elite and Bahram's affinity with Arsacids. Following the Islamic conquer, Bahram became a national hero in the Persian culture and a symbol of Iranian identity. 
taken on the tyrant who overthrew the legitimate dynasty ${ }^{81}$ was featured in the Emperor's official propaganda following 610 AD. The speech in book four is, therefore, a masterful technique used by Theophylact: the author presents the situation at the Persian court to the reader and justifies Roman intervention on behalf of the lawful dynasty of rulers, thus naturally flowing with the official stream of Heraclius' propaganda following 610 AD saying that tyrants i.e. usurpers should always be opposed.

Another speech is by an Avar envoy named Koch delivered before Priscus $^{82}$, the commander of Roman troops in the Balkans. Actions of Priscus were to be inflicted on the Slavs who had been crossing the Danube to find loot. Although the aim of the Roman army was to eliminate the threats within the imperial Balkans, the legions were allowed to cross the Danube to chase the Slavs under the agreements with the Avars. Notwithstanding the treaties, the Roman successes must have been worrying to the khagan of Avars, so he sent an envoy told to stop the Romans' triumphant procession. The nomads were intent on weakening the Empire, thus restoration of the Danubian limes was exceptionally unfavourable for them. In his ardent speech, sparing no bitter word to Priscus, Koch accused the Roman strategists of the breach of peace terms that he had personally negotiated with the khagan and of the resumption of warfare. Assumedly, the Avars felt attacked by the Romans although war was waged on the Slavs. The ambassador was not punished for his insolent words and the Roman commander emphasised that the war was not waged on Avars but on Slavs and that peace with the nomads does not mean the end to all the war. Notwithstanding the Avar mission, the Roman army continued its operations and attacked Ardagast's lands, ravaging them and winning great loots, which sparked another conflict with the Avars and stirred uproar within the Roman troops ${ }^{83}$. Koch's speech has been woven by Theophylact into the narrative about victorious campaigns. Mission from the Avars emphasised Roman successes and revival of the Empire in the Balkans. In this part of the Historiae, Priscus appears as a victorious leader dictating terms to the khagan himself, and a strategist with the most successful period after defeating Ardagast the Slav.

The speech of Priscus' ambassador - Theodor --addressed at the khagan demanding return of the loot taken from the Slavs ${ }^{84}$ should also be understood as a demonstration of Roman power. This circumstance was used by Theophylact to demonstrate his own erudition by referring to the famous tale of Sesostris. This was a hellenised name of Pharaoh Senuseret III (1870-1831 BC, $12^{\text {th }}$

${ }^{81}$ Cf. S.S. Alexander, Heraclius, Byzantine Imperial Ideology, and the David Plates, "Speculum" 52 (1977) fasc. 2, 217-237.

${ }^{82} \mathrm{Cf}$. Theophylactus Simocatta, Historiae VI 6, 7-12.

${ }^{83}$ The issue of negotiations with the troops on division of the loot was presented along speeches to the troops.

${ }^{84}$ Cf. ibidem VI 11, 9-18. 
Dynasty) and achievements of the great rulers from the $19^{\text {th }}$ Dynasty. Sesostris, whom the Greeks perceived as central figure in all the glory of Egypt and personification of all achievements of great pharaohs from Egyptian past, was quite well known in the literary culture of Antiquity and Theophylact's display should not be overestimated as a proof of his exceptional erudition ${ }^{85}$. The tale of Sesostris supposedly had a glaring effect on the khagan and taught him humility. Priscus did not give in in spite of the pressure from his own troops, and the barbarians were only returned the five thousand prisoners ${ }^{86}$ without being given any spoils of war ${ }^{87}$.

Another speech with the same objective is found in book seven ${ }^{88}$. In 595 $\mathrm{AD}$, the khagan moved on Singidunum (present-day Beograd), at the time an important Danubian fortress under his control for a year. The khagan's intent was to demolish the city's fortifications and deport the romanised civilians into the inland of Barbaricum. This meant that the recent successes of the Romans forced the khagan to act. Existence of a strong romanised fortress which could have become the Romans' outpost must have been a thorn in the nomads' side. Having learned of the Avars' actions, Priscus has taken decisive measures. Part of the Roman troops travelled the river on dromons ${ }^{89}$, and the rest have taken the land route. Haste was expedient because the city's situation was becoming very serious. Romans built a camp in Constantiola, after which the strategist personally went to negotiate with the khagan. Once again, Priscus acted from the position of strength. Khagan Bayan accused the Romans of resumption of warfare and invasion of Avar lands. From the Avar point of view, these charges were legitimate: Priscus' actions were demonstrative, the Romans did not want to lose an important and friendly outpost in the West Balkans, and at the time they felt secure enough to risk resumption of warfare to defend the city. In reply to the khagan's accusations, Priscus supposedly said that the war was resumed because of the Avars' greed, as the population of Singidunum did not deserve such treatment and had enough of the barbarians' oppression. Each of the two speeches is different: the khagan focuses on formal issues, while the Roman - defeated in this respect - changes the field of dispute and using a moral blackmail of a sort focuses on hybris - the favourite cause of all evil in Greek spirituality. The khagan - now deprived of moral authority - should

\footnotetext{
${ }^{85}$ Cf. Herodotus, Historiae II 107-110; Diodorus Siculus, Bibliotheca historia I 53-58; Ioannes Niciensis XVII 1.

${ }^{86}$ Cf. Theophylactus Simocatta, Historiae VI 11, 21.

${ }^{87}$ Cf. ibidem VI 11, 21. Although Theophylactus also stressed that Emperor Maurice was not pleased with this conduct of the strategos, the prisoners could have been a valuable bargaining chip.

${ }^{88}$ Cf. Ibidem VII 10-11.

${ }^{89}$ Cf. Ibidem VII 10, 3. The authors of The Age of the Dromon rightfully do not speak of the period of Maurice's rule, noting only the attempts of building a fleet in Italy. J. Pryor - E. Jeffreys, The Age of the $\triangle \mathrm{POMON}$. The Byzantine Navy ca 500-1204, Leiden 2004, 19-24, and a fragment of Simocatta's account in which he describes a ship on which Maurice fled Constantinople in 602 as a dromon (ibidem, p. 133).
} 
not have the right to protest and his arguments lose their strength. Evidently, Theophylact was demagogic in composing this conversation to manipulate the audience's emotions. In the outcome, the Romans managed without any fight to force the Avars to abandon the damaged city fortifications and to retreat, with a contribution from the population of Singidunum threatening the barbarians' rear. A few days later, a separate troop commanded by Guduis inflicted another heavy defeat on the Avars ${ }^{90}$. Priscus intervened on Singidunum's behalf although the city was located beyond the Roman sphere of influence. The official argument was protection of the local population at risk of displacement. Obviously, at the same time, Priscus secured an important base with strong fortifications and friendly population. All Roman actions prior to 595 $\mathrm{AD}$ show their desire to restore the limes based on the existing and populated border fortifications.

Book seven also features a full description of the official imperial mission sent to the Khagan of Avars. It took place at the time when the tide of war had already turned. Avar raids reached the Long Walls and the Senate of Constantinople began to persuade Emperor Maurice to commence negotiations with Bayan. Harmaton was appointed as the envoy and his job was to reach a compromise with the Avars ${ }^{91}$. It was to be easy as the barbarian troops were affected by a plague ${ }^{92}$ and their battle ardour significantly diminished. In spite of this, the khagan, grief-stricken after the death of his sons, received the envoy only after twelve days and treated him roughly. Bayan refused to accept rich gifts saying that:

"the gifts of enemies are not gifts and are worthless"93.

Harmaton must have been a good orator and the gifts extremely enticing because, after a long speech, the Roman diplomat managed to persuade the khagan to accept the valuables and sign the peace treaty ${ }^{94}$. Then, Bayan spoke and Theophylact emphasised that the first words of his speech are quoted unchanged:

"The Khagan said these exact words: Let God settle the dispute between Maurice and the Khagan, between Avars and Romans" ${ }^{\prime 95}$.

\footnotetext{
${ }^{90}$ Cf. Theophylactus Simocatta, Historiae VII 12, 2-8.

${ }^{91}$ Cf. ibidem VII $15,9$.

${ }^{92}$ Cf. Plague and the End of Antiquity The Pandemic of 541-750, ed. L. Little, Cambridge 2007; P. Horden, Mediterranean Plague in the Age of Justinian, in: The Cambridge Companion to the Age of Justinian, ed. M. Maas, Cambridge 2007, 134-161. Plagues in this period regularly affected the Mediterranean region.

${ }^{93}$ Theophylactus Simocatta, Historiae VII 15, 11, ed. de Boor - Wirth, p. 272, transl. by Authors. The khagan here quotes Ajax 665 (sic!). Aside from Euripides, Sophocles was the most frequently quoted playwright in the Byzantine literature.

${ }^{94}$ Ibidem VII 15, 11, ed. de Boor - Wirth, p. 272, transl. by Authors.

${ }^{95}$ Ibidem VII 15, 12, ed. de Boor - Wirth, p. 272-3, transl. by Authors. This statement by the
} 
Then, Theophylact only summarised the khagan's speech, presenting the key peace terms ${ }^{96}$. A special phrase ( record means that Theophylact was very well aware of the difference between oratio created as a literary composition and a quotation. It should be added that when Theophylact uses the phrase on quoting elsewhere (in particular in the case of letters), the researchers managed to confirm that he refers to actual correspondence. In the above-mentioned case, this historian had access to documents containing peace terms and took the quotation to include into the speech of his own authorship, written in accordance with the rules of writing. This is distinctly proven by the citation of Sophocles after which he declares that the words of the khagan shall thereafter be unchanged. This situation, on the whole, authenticates all of Theophylact's statements on his own works. The speech itself was used to bring forward the defeats sustained by the Romans. This time, it is the imperial diplomat in the asking role and the khagan was dictating the terms. Position of the Avars was strong enough to keep Harmaton waiting twelve days for an audience with Bayan which was surely an intentional behaviour still in use today in negotiations to humiliate the adversary and force him into submission.

Book eight mentions only one official diplomatic mission. At the end of Maurice's reign, Theophylact associated the events in the East with the Balkan campaigns of $598 \mathrm{AD}$ when Khosrow was planning to wage war on the Arab tribes allied with the Romans ${ }^{97}$. Having heard of this, Maurice sent his ambassador George to call the Persian king to order. The mission was successful but George received no reward for it because when rendering an account of it to Maurice he reportedly said that Khosrow spoke as follows:

"The King of Persians thus spoke to the listening satraps: it is for this envoy's bravery that I give up on the war" $" 98$.

Maurice concluded that the diplomat is trying to win the Emperor's favour and was enraged. This incident is very interesting. Firstly, the author returns to the East and yet again presents the historical background and the cause that sparked the conflict between the empires (and gives up including speeches used for this very purpose in the initial books). Secondly, the person of the emperor's own ambassador was used by the author as an example of wrongdoing

khagan is mentioned earlier: "Let God settle the dispute between the Khagan and Emperor Maurice. God's payment is to be expected" (ibidem VII 10, 8, ed. de Boor - Wirth, p. 263, transl. by Authors).

${ }^{96}$ Increase of the tribute paid to the Avars and restoration of Danube as the border river. This peace treaty also allowed both parties to cross the Danube to chase the Slavs.

${ }^{97}$ Cf. M. Whittow, Rome and the Jafnids: Writing the History of a Sixth-Century Tribal Dynasty, "Journal of Roman Archaeology Supplementary Series" 31 (1999) 207-224. and the following monograph: I. Shahîd, Byzantium and the Arabs in the Sixth Century, vol. 1, part 1: Political and Military History, Washington 1995.

${ }^{98}$ Theophylactus Simocatta, Historiae VIII 1, 7, ed. de Boor - Wirth, p. 284, transl. by Authors. 
and served as an excuse for a preaching discourse ${ }^{99}$. Theophylact judged the imprudent envoy by pronouncing that if there is no moderation in speech, the speech may turn against the speaker. It is interesting inasmuch as that previously the power of words served Roman diplomacy well and now it turned against its representative.

3. The army and demes in unison. Another category of independent speeches are those by representatives of the crowds. In his entire work, Theophylact gives voice to the community only a few times; first in the case of moving Philippicus from the battlefront to the rears during the battle of Solachon ${ }^{100}$, then at the time of mutiny of Priscus' troops, for the third time in Book VIII when the Blues sing to Maurice ${ }^{101}$, then in the same book when Germanos' offer is rejected by the Greens, ${ }^{102}$ and, lastly, in Book VIII when the Blues address Phocas ${ }^{103}$.

Although examples of such speeches are few, they have their established place in the composition of Theophylact' text. In each of these cases the community is given voice in a crisis situation. With his bravery, Philippicus wished to show his soldiers that he is not afraid of the upcoming battle, to which demonstration both archons and soldiers unanimously reacted by asking their commander to take a safer stand ${ }^{104}$. During the mutiny, the soldiers supposedly shouted to Priscus:

"Order among the troops has broken as the army seems to be deprived of command" 105 .

to emphasise the mutiny of all the troops against the change in command and the emperor's decisions. At the hippodrome, the Blues allegedly sang:

"God, Emperor, who commanded you to rule, will submit to you everyone fighting the imperial authority. If there is a Roman, our benefactor, who does not recognise you, let him be put [by God] in your captivity without bloodshed" 106 .

${ }^{99}$ Khosrow's statement made to the Roman commander John who mocked the lack of organisation among Persian troops is of similarly preaching nature although further part of the account also has strong religious marks. Cf. ibidem V 15.

${ }^{100} \mathrm{Cf}$. ibidem II 3 .

${ }^{101}$ Cf. ibidem VIII 7, 9.

${ }^{102}$ Cf. ibidem VIII 9, 15.

${ }^{103}$ Cf. ibidem VIII 10, 13.

${ }^{104}$ Ibidem II 3, 11, ed. de Boor - Wirth, p. 74-75, transl. by Authors. "Fight" - they said - "has no moments of calm, it is very diverse and has multiple forms; its nature is constant change and the only thing unfallible about it is its fallibility. Misfortune is more probable to occur more frequently than fortune".

${ }^{105}$ Ibidem III 1, 10, ed. de Boor - Wirth, p. 111, transl. by Authors.

${ }^{106}$ Ibidem VIII 7, 9, ed. de Boor - Wirth, p. 296-297, transl. by Authors. 
Thus declaring openly their support for the emperor at the outbreak of Phocas' mutiny. Another case of the voice given to demes were the Greens who rejected the offer of Germanus who agreed to accept the imperial crown on certain conditions. The factionists supposedly said:

"Germanus will never change his political ways or ways of thinking being all the time closely tied to the Blues" 107 .

The Blues, meanwhile, allegedly shouted at Phocas after seizing Constantinople:

"Begone! Know your situation, Maurice is not dead!"108

This is how they warned him that a usurper cannot go too far as long as the emperor lives ${ }^{109}$. In each of these cases, giving voice to the nameless crowd, Theophylact emphasised that they were unanimous and right. In each case, it is a purposeful operation by which the author wished to additionally increase the importance of this event and draw the readers' attention to the determination and common goal of the masses.

4. Imperial speeches. Another distinctive category are speeches delivered by emperors. In Theophylact's work, these are rare and voice is given to three emperors (Justinian II, Tiberius, and Maurice). Speeches of the rulers were purposefully used by Theophylact as introductions, similarly to some of the diplomats' speeches. All imperial speeches are hugely important for the entire text's composition. The first speech in the work is Tiberius' declaration on elevation of Maurice as a co-ruler ${ }^{110}$. Theophylact used this opportunity as a perfect pretext to present the main participants of the events. In the opening words of his speech, Emperor Tiberius briefly describes his rule and the trials and tribulations he experienced during his rule, putting forward the fact that for the good of the state he had neglected his wife and children, including the daughter that he is now giving over as wife to the right person, to Maurice. In Tiberius' words, Theophylact also describes all the virtues of the future emperor Maurice and gives words of warning on how to rule usefully and well. He also gives definition of true power:

"For the sceptre of imperial authority does not mean a willful rule but a noble service" $" 11$.

Maurice is, therefore, presented as a prudent and hard-working man, who previously:

${ }^{107}$ Ibidem VIII 9, 15, ed. de Boor - Wirth, p. 302, transl. by Authors.

${ }^{108}$ Ibidem VIII 10, 13, ed. de Boor - Wirth, p. 304, transl. by Authors.

${ }^{109}$ Cf. Y. Janssens, Les Bleus et les Vertes sous Maurice, Phocas et Heraclius, "Byzantion" 11 (1936) 499-536. On importance of circus factions in Constantinopolitan politics.

${ }^{110} \mathrm{Cf}$. Theophylactus Simocatta, Historiae I 1, 5-21.

${ }^{111}$ Ibidem I 1, 18, ed. de Boor - Wirth, p. 41, transl. by Authors. 
"Undertook the numerous, serious problems of the Roman state, as a presage shown by him as a sign of his future providence over his subjects" $" 12$.

Theophylact treated this man whose rule marks chronological framework of the entire work very kindly and presented Maurice as a leader with great qualities of character previously tried in difficult situations.

Another speech was addressed at the emperor by John, the Patriarch of Constantinople. Narration in the trial of a man accused of witchcraft is anecdotal $^{113}$. Theophylact presents the trial for witchcraft practised by one of the Constantinople's patricians named Paulinus. Paulinus was accused of witchcraft by the Bishop of Heraclea who bought a silver bowl from him; subsequently, Patriarch John was involved in the case personally and requested the emperor to punish the culprit. Maurice supposedly was not the advocate of severe penalty, wishing to restore Paulinus to the true faith, but John in his fiery speech convinced the emperor to sentence the culprit to death (impalement and burning). The speech and the anecdote itself were a perfect excuse for Theophylact to demonstrate his religious beliefs. The Historiae's author turned out to be a devout advocate of orthodoxy, believing any deviations from the faith a mortal sin for which the capital punishment should be administered. The speech has no sign of defence of Paulinus, even a shade of doubt as to rightness of the accusation and cruelty of the punishment. In the work a few more proofs of Theophylact's great commitment to religious affairs can be found, for instance the speech made by a local priest following the capture of Martyropolis ${ }^{114}$. Taking the city back from the Persians was used by Theophylact to present his opinion on the inhabitants of Chalcedon who allegedly previously had given the city over to the enemy. The entire speech is in the style of vague religious symbolism, it is full of pompous yet not too specific phrases. In terms of density of biblical or more broadly religious metaphors, poorly written, there is nothing in all of the Historiae that this speech could be compared to. Note also the punishment administered to Sittas for treason strategist Comentiolus sentenced him to being burned alive. Such punishment was nothing new or special ${ }^{115}$ but in Theophylact's work it was reserved only for traitors of the faith. Thus, Theophylact used speeches twice to present his religious beliefs and it gives rise to a conclusion that his opinion aligned with the official religious doctrine of Emperor Heraclius ${ }^{116}$. It is possible that this strong religious emphasis in a historical work was intentional, aimed by the

${ }^{112}$ Ibidem I 1, 12, ed. de Boor - Wirth, p. 40, transl. by Authors.

${ }^{113}$ Cf. ibidem I 11.

${ }^{114}$ Cf. ibidem IV 14-16.

${ }^{115}$ Burning alive was set aside for deserters: "Hostes autem, item transfugae ea poena adficiuntur, ut vivi exurantur" (Digesta Iustiniani XLVIII 19, 8, 2).

116 Cf. W.E. Kaegi, Heraclius Emperor of Byzantium, Cambridge 2003, 58-99. See also: S.J. Shoemaker, "The Reign of God Has Come": Eschatology and Empire in Late Antiquity and Early Islam, "Arabica” 61 (2014) 535-541. 
author at winning the emperor's favour or making his work a part of the official stream of imperial propaganda.

Another speech made by an emperor is proclamation of Tiberius by the abdicating Justin II. In this case, it is probably the original text transcribed from the official documents. To confirm our assumptions, Theophylact says in the foreword to this speech:

"Without embellishing the words or transforming the style with ornaments,

I will quote a bare narration in my story, so that the honest and true words, in accordance with their nature, show the authenticity of the message" 117 .

Please note the aggregation of terms defining fidelity of the transmission on

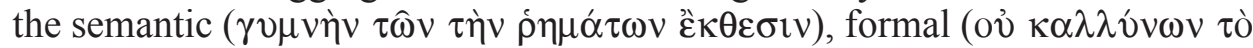

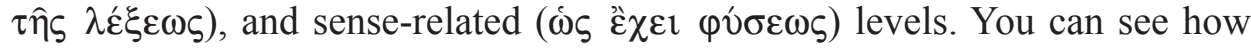
much Theophylact was intent on leaving the readers with no doubt as to the authenticity of the emperor's words. The speech itself was analysed many times and the accounts of it being made are also found in other sources ${ }^{118}$. In this case the point of interest is why Theophylact decided to put its original record in his work. He explained it in the foreword to the citation:

"But before we present the actions of Bahram and events connected with Khosrow the Younger's access in detail, let us again guide the story to the rule of Justin the Younger, going with the narration back in time. We will now present the causes of this ancient Persian conflict: thus the tables of historical narration will be ornamented by complete content" 119 .

In book one of his work, Theophylact presents a brief description of the Persian-Roman conflict ${ }^{120}$ without going into historical details. The reader is informed by the author of the ongoing war and the tilting balances of the conflict, and in combination with the narration preceding the $586 \mathrm{AD}$ campaign described in book two such information were sufficient. When Rome became involved in internal affairs of Persia, Theophylact had to extend his narration which required providing the reader with more information. Internal affairs

${ }^{117}$ Theophylactus Simocatta, Historiae III 11, 6, ed. de Boor - Wirth, p. 132, transl. by Authors.

${ }^{118}$ Cf. Evagrius Scholasticus, HE VI 13, and Ioannes Ephesius, HE III 5. The above speech and its importance for the later Byzantine historiography have been discussed in detail by В.Е. Вальденберг, Речь Юстина II к Тиберию, “Известия Академии Наук СССР” VII/2 (1928) 111-130; В. Е. Вальденберг, Речь Юстина II в древнерусской литературе, “Доклады Академии Наук CCCP" B/7 (1930) 121-127. These works are unknown to A. Cameron, An Emperor's Abdication, "Byzantinoslavica" 37 (1976) 161-167. The record of this speech has the form of admonitions taken out of the narration flow and is undoubtedly authentic. Author of this record took down a list of emperor's recommendations, the stenographic procedure is mentioned by John of Ephesus in his account, see also P. Nitzschke, Stenographische Niederschrift einer griechischen Kaiserrede, "Archiv für Stenographie" 62 (1911) 64-68.

${ }^{119}$ Theophylactus Simocatta, Historiae III 9, 1, ed. de Boor - Wirth, p. 127-128, transl. by Authors.

${ }^{120}$ Obviously, this reference is about Mebodes' speech. 
of the Persian court have been described by Theophylact in Hormisdas' trial while the issues of relationships between the two powers have been described in the introduction to actions taken against Bahram. Theophylact cleverly used historical digression on foreign policy to present the circumstances of Tiberius' accession to the imperial throne. Note here the speech ending the entire digression and, thus, book three being an integral part of historical narration. Theophylact presented a speech by strategist Justinian who had to face the Persian army commanded by Hormisdas himself under the walls of Daraa ${ }^{121}$. Theophylact accounted the battle as a clash of huge armies but actually this battle has never taken place. Justinian's speech in a dramatic moment which could have changed the fates of war was aimed at emphasising Simocatta's point of view. The author presents the qualities of both nations in the words of strategist Justinian, sparing no praise to the Persians while reminding of their mortality. With rhetoric displays, he roused the troops by emphasising the legitimacy of the Roman cause. Most of the speech was a typical speech to the troops before a battle, aimed at raising the audience's morale, and only in the end does Theophylact start an attack to reveal the true meaning of this fragment. Justinian addressing Roman troops allegedly concluded his speech by comparing the two state religions and strongly refuting the Persian rituals as superstitions which must give way to the true $\operatorname{God}^{122}$. In the last sentences, Theophylact's enmity to the Persian religion is evident. It is even unpleasant when he calls Zoroastrian altars of fire defiled altars and, in addition to this, claims that the Persians worship horses ${ }^{123}$. Clearly in discussing religious issues Theophylact is more radical than in political issues where he believed there is room for agreement (e.g. maintenance of peace). When using religious metaphors, on the other hand, our historian loses control of himself and lets himself be controlled by emotions.

Note also the two short orationes rectae in book VIII where Emperor Maurice speaks. In the first case, the ruler allegedly referred to the speech in which Germanus ${ }^{124}$ tried to prove that he did not crave for the purple by saying:

"Pray, Germanus, spare us this longish speech: there is nothing sweeter than to die by the sword" 125 .

The emperor allegedly spoke directly before the execution by addressing God in philosophical words:

${ }^{121}$ Cf. ibidem III 13, 1.

${ }^{122}$ Cf. Dignas - Winter, Rome and Persia, p. 149. This does not mean that the rulers of Persia and Rome would not skilfully play the religious card when need arose.

${ }^{123}$ Theophylactus Simocatta, Historiae III 13, 13-16.

${ }^{124}$ When leaving the secretum room, Germanus was supposedly warned by Theodosius - his son-in-law and Maurice's son - with the following words: "flee him, man, you have been sentenced to death" (ibidem VIII 8, 10, ed. de Boor - Wirth, p. 298-9, transl. by Authors).

${ }^{125}$ Ibidem VIII 8, 9, ed. de Boor - Wirth, p. 298, transl. by Authors. 
"Just you are, my Lord, and Thy sentence is just!"126

Both short utterances of the emperor were aimed at emphasising Maurice's dignified conduct in the last moments. Interestingly, the number of details ${ }^{127}$ in the unrecorded speech of Germanus and Maurice's reply (Theophylact noted that Theodosius had to move to be able to whisper the words of warning to his father-in-law) might mean that the historian used a verbal account of a witness to these events.

The above outline aimed at showing the role and importance of speeches in the narration of Historiae by Theophylact Simocatta allows several conclusions. Firstly, in the use of oratio recta the author does not in any way diverge from the classical standards. He also clearly distinguishes it from the passive voice. Orationes are aimed at presenting the historian's point of view and bringing forward the issues that he was particularly intent on presenting in a reliable manner. Nevertheless, it should be noted that Theophylact very clearly draws the division mark between a speech composed by himself in line with the convention and a literal citation. At the same time, he realises that the reader is also perfectly aware of the speech-writing rules and must be given a clear indication of the above difference. There are, however, unique characteristics of speeches, expressing the writer's individuality. First of all, accumulation of axiological terminology is noticeably greater than in the rest of the narration. It is frequently enclosed in rich metaphors which are, however, quite clumsy and definitely not satisfactory for the readers in aesthetic terms, in particular in the two religious speeches. Finally, the religious speeches referred to above reveal quite an emotional spirituality of Theophylact to which this historian's reliability is sacrificed.

\section{ROLA I MIEJSCE MÓW W DZIELE TEOFILAKTA SYMOKATTY}

\section{(Streszczenie)}

Powyższy artykuł poświęcony został analizie mów (tzn. wypowiedzi w oratio recta) w Historii powszechnej Teofilakta Symokatty, najważniejszym dziele historiografii bizantyńskiej pierwszej połowy VII w. Przeprowadzony przegląd pozwolił na dokonanie konkretnych ustaleń. Mianowicie, Teofilakt w pełni akceptuje rolę kompozycyjną mów (zgodnie z tradycją klasyczną) w aspekcie a) mowy jako możliwość wypowiedzi własnej autora, b) mowy jako środek wzmocnienia

\footnotetext{
${ }^{126}$ Ibidem VIII 11, 3, ed. de Boor - Wirth, p. 305, transl. by Authors.

${ }^{127}$ Aside from mentioning the emperor's son's whispering, Theophylact has specifically reported that Theodosius had to move to be able to whisper the words of warning to his father-in-law.
} 
płaszczyzny aksjologicznej, tzn. to, co mówione posiada wiarygodność wyższą od tego, co przekazane w mowie pośredniej (oratio obliqua itp.). Niemniej, uważna lektura pozwoliła wyodrębnić cechy szczególne stylu Teofilakta. Są nimi: nadmierna afektacja, brak dobrego smaku w doborze egzemplów i, niestety, nadużywanie argumentacji religijnej, zbliżające się do fanatyzmu (chociaż w tym ostatnim wypadku należy przeprowadzić badania, by stwierdzić, czy jest to kwestia osobista, czy 'duch czasów', tzn. polityka religijna Herakliusza).

To, co zasługuje na uznanie, to dbanie o aspekt formalny. Teofilakt bardzo wyraźnie zaznacza te partie tekstu w mowie niezależnej, których nie stworzył, lecz wiernie cytował z dostępnej mu dokumentacji. Używa przy tym ścisłej i jednoznacznej terminologii filologicznej. Zabieg ten świadczy o rozumieniu, zarówno przezeń, jak i jego odbiorców, konwencji związanej z komponowaniem mów.

Podsumowując, w zakresie przedmiotowym poddanym badaniu, Historia powszechna Teofilakta Symokatty spełnia standardy historiografii późnoantycznej.

Key words: Theophylact Simocatta, Byzantium, oratio recta, Literary topos, speeches.

Słowa kluczowe: Teofilakt Symokatta, Cesarstwo Bizantyńskie, oratio recta, toposy literackie, mowy.

\section{BIBLIOGRAPHY}

\section{Sources}

Digesta Iustiniani Augusti, rec. P. Kruegero - Th. Mommsen, Berolini 1870.

Diodorus Siculus, Bibliotheca historica, vol.1, ed. I. Bekker - L. Dindorf, rec. F. Vogel. Leipzig 1888.

Evagrius Scholasticus, ed. J. Bidez - L. Parmentier: The ecclesiastical history of Evagrios with the scholia, London 1898.

Herodotus, Historiae, ed. E. Legrand: Hérodote, Histoires, vol. 1-9, Paris 1932 (vol. 1), 1930 (vol. 2), 1939 (vol. 3); 1960 (vol. 4), 1946 (vol. 5), 1948 (vol. 6), 1951 ( vol. 7), 1953 (vol. 8), 1954 (vol. 9).

IoAnNes Ephesius, Historia ecclesiastica, ed. E.W. Brooks: Johannis Ephesini historiae ecclesiasticae pars tertia, Löwen 1952.

Mauricius, Ars militaris, ed. G.T. Dennis: Das Strategikon des Maurikios, transl. E. Gamillscheg, Wien 1981.

Res Gestae Divi Augusti ex Monumentis Ancyrano, Antiocheno, Apolloniensi, ed. C. Barini, Rome 1937.

Theophylactus Simocatta, Historiae, rec. I. Bekkerus: Theophylacti Simocattae Historiarum, Bonnae 1834; ed. C. de Boor - P. Wirth, Stutgardiae 1972, transl. Н.В. Пигулевская - С.П. Кондратьев: Феофилакт Симокатта, История, Москва1957; transl. M. and M. Whitby: The History of Theophylact Simocatta an English Translation with Introduction and Notes, Oxford 1986.

\section{Works}

Alexander S.S., Heraclius, Byzantine Imperial Ideology, and the David Plates, "Speculum" 52 (1977) fasc. 2, 217-237. 
Avenarius A., Die Awaren in Europa, Bratislava 1974.

ВАльДЕНБеРГ В.Е., Речь Юстина II в древнерусской литературе, “Доклады Академии Наук СССР”, В/7 (1930) 121-127.

ВАльДЕНБЕРГ В.Е., Речь Юстина II к Тиберию, “Известия Академии Наук СССР” VII/2 (1928) 111-130.

BALdwin B., Theophylact's Knowledge of Latin, “Byzantion” 47 (1977) 357-360.

Bauman R., Verbal Art as Performance, "American Anthropologist” 77 (1975) fasc. 2, 290-311.

Bers V., Speech in Speech. Studies in Incorporated Oratio Recta in Attic Drama and Oratory, London - New York 1997.

Bury J., The Chronology of Theophylaktos Simokatta. "The English Historical Review" 3 (1888) 310-315.

Cameron A., An Emperor's Abdication, "Byzantinoslavica" 37 (1976) 161-167.

Clark M., Did Thucydides Invent the Battle Exhortation?, "Historia" 44 (1995) 375-376.

CRANE G., Thucydides and the ancient simplicity. The limits of political realism, Berkeley 1998.

Czeglédy K., Bahram Čobin and the Persian Apocalyptic Literature, "Acta Orientalnia Academiae Scientiarum Hungaricae" 8 (1958) fasc. 1, 21-43.

Dignas B. - Winter E., Rome and Persia in Late Antiquity Neighbours and Rivals, Cambridge 2007.

East Rome, Sasanian Persia and the End of Antiquity, ed. J. Howard-Johnston, Farnham 2006.

Flashar H., Der Epitaphios des Pericles. Seine Funktion im Geschichtswerk des Thukydides, Heidelberg 1969.

Fritze W.H., Zur Bedeutung der Awaren f. d. Slavische Ausdehnungsbewegung im frühen Mittelater, "Zeitschrift für Ostforschung" 28 (1979) 498-545.

Gaiser K., Das Staatsmodell des Thukydides. Zur Rede des Perikles $f$. die Gefallenen, Heidelberg 1975.

Goldsworthy A., The Roman Army at War 100 BC-AD 200, New York 1996.

Greek Ritual Poetics, ed. D. Yatromanolakis - P. Roilos, Cambridge (Mass.) 2005.

Haldon J., The Byzantine wars: battles and campaigns of the Byzantine era, Charleston 2001.

Hansen H.M., The Battle Exhortation in Ancient Historiography. Fact or Fiction?, "Historia" 42 (1993) 161-180.

Harding H.F., The Speeches of Thucydides. With a General Introduction and Introductions for the Main Speeches and the Military Harangues, Lawrence 1973.

Honigmann E., Die Ostgrenze des Byzantinischen Reches von 363 bis 1071 nach griechischen, arabischen, syrischen und armenischen Quellen, Bruxelles 1935.

Howard-Johnston J., Witnesses to a World In Crisis Historians and Histories of the Middle East in the Seventh Century, Oxford 2011.

Hunger H., Die hochsprachliche profane Literatur der Byzantiner, Bd. 1, München 1978.

Hunger H., On the Imitation (MIMH $\Sigma \mathrm{I} \Sigma$ ) of Antiquity in Byzantine Literature, DOP 23-24 (1969-1970) 15-38.

JANIn R., Constantinople byzantine. Développement urbain et Répertoire topographique, Paris 1951.

Janssens Y., Les Bleus et les Vertes sous Maurice, Phocas et Heraclius, "Byzantion" 11 (1936) 499-536.

JENKIns R., The Hellenistic Origins of Byzantine Literature, DOP 17 (1963) 37-52. 
JoHanson D., Monks of Mount Izla, Orgins of Monasticism In Upper Mesopotamia In the 4th-6th centuries Translations and Analysis from previously unpublished Syriac Manuscripts, Washington 2004.

JuREwiCz O., Historia literatury bizantyńskiej, Wrocław 1984.

KAEGI W.E., Heraclius, Emperor of Byzantium, Cambridge 2007.

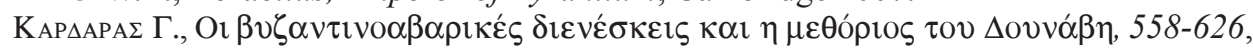

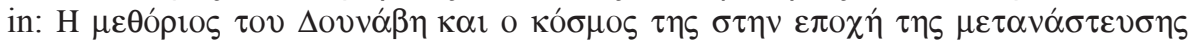

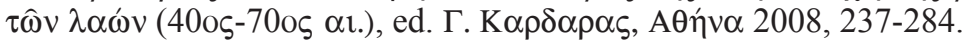

KotŁowska A. - Różycki Ł., The Battle of Solachon of 586 in light of the works of Theophylact Simocatta and Theophanes Confessor (Homologetes), "Travaux et Mémoires" 19 (2015) 315-327.

Kretschmer P., Die slavische Vertretung von indogerm. o., "Archiv für Slavische Philologie" 27 (1905) 228-240.

Krivouchine I.V., La révolte pres de Monocarton vue par Évagre, Théophylacte Simocatta et Théophane, "Byzantion" 63 (1993) 154-173.

Krivushin I.V., Theophylact Simocatta'sConception of Political Conflicts, "Byzantinische Forschungen" 19 (1993) 171-183.

Krumbacher K., Geschichte der byzantinischen Literatur, München 1897.

Labuda G., La Chronologie des guerres de Byzance contre les Avares et les Slaves à la fin du VIe siècle, "Byzantinoslavica" 11 (1954) 167-173.

Landmann O.P., Die Totenrede des Thukidydes, Bern 1945.

LeE A., War in Late Antiquity. A Social History, Oxford 2007.

LeWANDOWSKi I., Recepcja rzymskich kompendiów historycznych $w$ dawnej Polsce (do połowy XVIII wieku), Poznań 1976.

LewIS N., On the Chronology of the emperor Maurice, "American Journal of Philology" 60 (1939) 414-421.

Loraux N., The Invention od Athens, The Funeral Oration in the Classical City, Harvard 1986.

MacheK V., Etymologický slovnik jazyka českého, Praha $1968^{2}$.

MaIER E., Reported Speech in the Transition from Orality to Literacy, "Glotta" 91 (2015) 152-170.

МахлАЮк А.В., Ропь ораторского искусства полководияа в идеологии и практике военного пидерства в древнем Риме, “Вестник Древней Истории” 1/248 (2004) 31-48.

Miller R.F., In Words and Deeds. Battle Speeches in History, Hanover - London 2008.

Mulligan B., öp $\alpha$ Introducing Direct Speech in Herodotus, "Mnemosyne" 60 (2007) 281-284.

NIEMINEN E., Über ein vermutliches urslawisches Lehnwort im Ostseefinnischen, "Die Welt der Slawen" 3 (1958) 101-123.

Nitzschke P., Stenographische Niederschrift einer griechischen Kaiserrede, "Archiv für Stenographie" 62 (1911) 64-68.

Olajos T., Données et hypothèses concernant la carrière de Théopbylacte Simocatta, Acta Classica Universitatis Scientiarum Debreceniensis 17-18, Debrecini 1983, 40-41.

Pelling Ch., Speech and Narrative in the Histories, in: The Cambridge Companion to Herodotus, ed. C. Dewald - J. Marincola, Cambridge 2006, 103-121.

Plague and the End of Antiquity The Pandemic of 541-750, ed. L. Little, Cambridge 2007. Pohl W., Die Awaren. Ein Steppenvolk in Mitteleuropa 567-822 n. Chr., München 1988. PolaceK J., Heraclius and the Persians in 622, "Bizantinistica" 10 (2008) 105-124. 
Preiser-Kapeller J., Erdumn, ucht, carayut'iwn Armenian Aristocrats as Diplomatic Partners of Eastern Roman Emperors 387-884, "Armenian Review" 52 (2010) 139-215.

PRICE J.J., Thucydides and internal war, Cambridge 2001.

Prostko-Prostý́ski J., „Ziemia ich nie zna żelaza”. Glosa do Historiae VI. 2 Teofylakta Simokatty, in: Viator per devia scientiae itinera, red. A. Michałowski - M. Teska - M. Żółkiewski, Poznań 2015, 321-326.

Pryor J. - JefFreys E., The Age of the $\mathrm{PPOMON}$. The Byzantine Navy ca 500-1204, Leiden 2004.

Roilos P., Amphoteroglossia. A Poetics of the Twelfth-Century Medieval Greek Novel, Cambridge Mass. 2005.

Roisman J., The General Demosthenes and his Use of Military Surprise, Stuttgart 1993.

Romilly de J., Histoire et raison chez Thucydide, Paris 1956.

RóżYcki Ł., Próby reformy finansów armii rzymskiej w czasach Maurycjusza (582-602), in: Ekonomia a wojna studia i szkice, red. M. Franz, Toruń 2011.

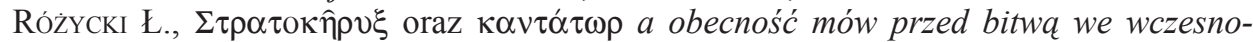
bizantyńskich traktatach wojskowych, ,De Re Militari” 2 (2015) 21-33.

ShaнîD I., Byzantium and the Arabs in the Sixth Century, vol. 1, part 1: Political and Military History, Washington 1995.

Shevelov G.Y., A Prehistory of Slavic, Heidelberg 1964.

Shoemaker S.J., "The Reign of God Has Come”: Eschatology and Empire in Late Antiquity and Early Islam, "Arabica" 61 (2014) 535-541.

Sinko T., Echa klasyczne w literaturze polskiej, Kraków 1923.

Słownik Starożytności Słowiańskich, red. S. Urbańczyk - M. Plezia, t. 1, Wrocław Warszawa - Kraków 1961.

Solmsen L., Speeches in Herodotus'Account of the Battle of Plataea, CPh 39 (1944) fasc. 4, 241-253.

StabryŁa S., Antyk we współczesnej literaturze polskiej, Wrocław 1980.

Strassler R.B., The Landmark Thucydides: A Comprehensive Guide to the Peloponnesian War, New York 1996.

Szafarzyk P., Słowiańskie Starożytności, Poznań 1844.

The Cambridge Companion to the Age of Justinian, ed. M. Maas, Cambridge 2007.

The Historian's Craft in the Age of Herodotus, ed. N. Luraghi, Oxford 2007.

Turasiewicz R., Pericles 'Funeral Oration' and Its Interpretation, "Eos" 83 (1995) 33-41.

VASMER M., Die Slaven in Griechenland, Berlin 1941.

Whiтвy M., The Emperor Maurice and his Historian Theophylact Simocatta on Persian and Balkan Warfare, Oxford 1988.

Wнiтву M., Theophylact's Knowledge of Languages, "Byzantion” 52 (1982) 425-428.

Whitтow M., Rome and the Jafnids: Writing the History of a Sixth-Century Tribal Dynasty, "Journal of Roman Archaeology Supplementary Series" 31 (1999) 207-224.

WoŁoszyn M., Teofilakt Simokatta i Stowianie znad Oceanu Zachodniego - najstarsze świadectwo obecności Słowian nad Battykiem, Kraków 2014.

ZÁstěrová B., Les Avares et les Slaves dans la Tactique de Maurice, Praha 1971.

ZıóŁkowski J., Thucydides and the Tradition of Funeral Speeches at Athens, New York 1981. 